\title{
Risk, Prevention and Early Intervention: Youth Justice Responses to girls
}

\section{Paper Type: Conceptual Paper}

Keywords: Risk, Prevention, Early Intervention, Girls, Youth

\section{Justice}

\section{Abstract}

\section{Purpose:}

The purpose of the paper is to examine the discourses of risk, prevention and early intervention, with particular reference, the treatment of girls in the contemporary Youth Justice System.

\section{Design:}

The paper has two broad objectives: firstly, the paper reviews the literature on early intervention and youth crime prevention policy. Secondly, the paper focuses on youth justice practice in relation to girls who are engaged in youth justice processes or "at risk" of criminal involvement.

\section{Findings:}

The paper argues that: girls are drawn into the system for welfare rather than crime-related matters; and youth justice policy and practice seems to negate girls' gender-specific needs. Moreover, the paper highlights research evidence and practice-based experience, and contends that youth justice policy and practice must be re-developed in favour of incorporating gender-specific, child and young person centred practices.

\section{Value:}


The results presented in this article will be particularly pertinent to policy makers, educators and practitioners in the sphere of youth justice, especially since the contemporary youth justice system, in its rigorous, actuarial pursuance of risk management, fails to distinguish between "gender" within its formulaic assessment documentation.

\section{Introduction}

The very effort to prevent, intervene ... and "cure" persons of their alleged pathologies, may ... precipitate or seriously aggravate the tendency society wishes to guard against.

(Matza, 1969:80)

When a youth commits a crime and we let him go, then the probability that he will do another crime is actually lower than if we'd punished him.

(Von Liszt, 1893, cited in Goldson, 2008:89)

As the above quotes attest, benevolently constructed early-preventative measures designed to hinder the onset of an offending career, certainly have the potential to impact negatively upon young people. As Whyte, (2004:5) observes 'overly formal, legalistic, and criminal responses to children run the risk of being counterproductive'. More specifically, the approach may instil, within the individual, a sense of negativity, internalising the blame and unintentionally sustaining the offender label (Blackmore, 1984). This may produce the direct opposite of what was intended, principally resulting in the young person presenting with further difficulties and/or committing further criminal offences (Matza, 1969). Nevertheless, early interventionist policies have been premised on a stern belief that to intervene early in the life course of young people is an 'effective' measure (Smith, 2003), and have persistently been deployed to deal with 'those deemed to be potentially problematic' (Armstrong, 
2004:104) or those 'children who paddle at the shallow end of 'anti-social behaviour ...' (Goldson, 2005a:262). In turn, the burgeoning popularity with targeting young people 'at risk' has resulted in vast numbers of young people drawn into a formal youth justice apparatus, which, operates within a populist-punitive context (Goldson, 2008).

This then, arguably harmful, early-preventative approach is apparent in practice when we consider the impact of Youth Inclusion and Support Panels (YISPs), and their counter-productive, potentially damaging, and net-widening tendencies (Walker, et al., 2007). This paper critically examines these matters located in contemporary youth justice policy and practice responses to 'at risk' youth, most specifically in relation to the discourses of risk, prevention and early intervention. Furthermore, it might be argued that such practice responses - in part because they tend to be gender neutral - can be particularly problematic when applied to girls. There is 'disturbing evidence that girls continue to be drawn into the youth justice system for welfare reasons...' (Sharpe, 2009:254). This article proceeds to consider the involvement of girls in the Youth Justice System (YJS), critically examining the perception and subsequent treatment of girls who offend or who are defined to be 'at risk' of criminal involvement. Finally, there is a detailed review of the literature in relation to the potential for re-developing youth justice policy and practice in favour of incorporating gender-specific imperatives. Arguably, the paper demonstrates the need for less resort to the formal youth justice apparatus and alternately locates important research and practice-based evidence, fundamentally concluding that practice should be driven by a system that operates in accordance with 'informalist principles' (Goldson, 2005b; Sharpe, 2011). Importantly, as distinct from operating within a punitive-context where young people are likely to experience damaging outcomes via labelling, stigma and criminalisation (Case, 2006), practice should aspire towards 'a principled youth justice' (Goldson and Muncie, 2006a) 'with integrity' (Goldson and Muncie, 2007): principally, 
'recognising that young people require a different, more balanced and less punitive approach (Solomon and Blyth, 2007:6).

\section{Early Preventative Intervention and the Ideology of Risk}

Historically, the construction of policy and development of practice in the youth justice arena has been 'riddled with paradox irony ... contradiction...' (Harris and Webb, 1987:79) '... ambiguity and compromise ...' (Muncie, and Hughes, 2002:1). Notwithstanding this observation, whereas welfare, justice, and children's rights, at varying times, have been dominant paradigms in juvenile/youth justice history, the contemporary focus has shifted towards a risk-conscious policy and practice agenda (Case, and Haines, 2009) 'whereby youth justice policy is no longer "hampered" by any adherence to competing philosophical principles and/or ideological convictions' (Goldson and Yates, 2008:111). Understanding that, the general consensus in contemporary society, seems to hold that young people are ostensibly 'unpredictable' and 'risky' - to themselves and to others (Goldson, 2003), Case (2010:90) stipulates that:

... risk-based responses have pervaded youth justice policy and practice to the point that the notion of risk (factors) underpins all work with young people who enter the youth justice system.

This ideology of risk, igniting regulation and control over young people's lives through various forms of 'intrusive' social and criminal justice measures (Kemshall, 2008), incorporates a vision of young people as: 'problem youth', dangerous, and threatening (Case and Haines, 2009). Ostensibly driven by adult anxieties (Fionda, 2005), these are dominant perceptions in contemporary society which result in children and young people being viewed to be either 'posing a risk' or depicted as 'at risk' (Armstrong, 2004, 2006). More than this, young people continue to be demonised and their attitudes and behaviours continue to be overregulated (Smith, 2003). Young people are persistently viewed in a 
negative light: policy and practice does not reflect, nor contemplate, any understandings that young people are arguably more 'at risk of labelling, stigmatization, and invasive intervention...' via the formal youth justice apparatus (Case, 2006:173). Nonetheless risk-led measures are purported to be value-free, scientifically objective, and are predicated upon a seemingly impressive predictive accuracy (Farrington, 2005; Hansen and Plewis, 2004). Proponents of these risk-led measures declare that 'causes' can be established with regard to the offending behaviour detected or problematic behaviour suspected (Farrington, 1997). It is believed that solutions to that problematic/offending behaviour can be accurately devised to prevent further instances arising: 'the basic idea ... is very simple: identify the key risk factors for offending and implement prevention methods designed to counteract them' (Farrington, 1997:606). However, contrary to this belief, the evidence suggests that most young people displaying risk factors do not offend (Smith and McVie, 2003) and for those that do, the vast majority 'grow out of it' with 'minimalintervention' (Rutherford, 1992). Conversely, it seems that ignoring clear scientific evidence and thus allowing the young person to offend 'unimpeded' is a clear missed opportunity (Farrington, 2005). In contrast, however, the mantra of 'it's what works that counts' and the accompanied eagerness to apply evidence-based solutions are greatly difficult to implement in practice when applied to young people's individual lives, that comprise 'often complex social difficulties' (Whyte, 2004). What's more, the process of screening, identifying and targeting increasingly younger children on the basis of 'spurious prediction' (Goldson, 2005a) and pre-emptively intervening in their life-course is certainly concerning. This process not only violates the child's human rights (Smith, 2010) but is also 'antithetical to long-established principles of criminal justice ...' (Goldson, 2005a:263), with the potential to create further difficulties for that individual young person (Burnett, 2007). 
Essentially early-preventative measures violate due-process safeguards, 'designed to protect the defendant's rights and liberties before a conviction can be satisfactorily obtained and before any punishment can be wholly justified' (Fionda, 2005:106). This favoured early-preventative method, worryingly, 'seek[s] to process suspects and punish them at the earliest possible stage of the criminal justice process, avoiding wherever possible the opportunity for dispute, contention or appeal' (Fionda, 2005:106). On the other hand, David Farrington 'one of the most influential figures in risk factor research' (Garside, 2009:4) supports the contemporary focus on tackling identifiable risk factors that correlate with offending behaviour and encourages the development of this type of approach to 'effectively' prevent youth crime and tackle anti-social behaviour. Farrington (2005:244) goes on to assert that:

Early identification and preventative intervention seems likely to be an effective strategy to prevent crime. As with public heath, prevention is better than cure.

It is unsurprising that concern has centred towards developing 'effective' youth crime prevention strategies (Farrington, 2005), particularly when we consider that concern toward young people involved in criminal activity has always been of significant interest to the general public (Pearson, 1983). However, notwithstanding this, and the political obligation to acknowledge 'the need to punish for wrong-doing and to demonstrate disapproval' (Eadie and Canton, 2002:14), targeting and intervening in the lives of those judged to be 'pre-criminal', may not only be described as 'pre-cautionary injustice' (Smith, 2010; Squires and Stephen, 2005), but, as discussed above, is fundamentally neglectful towards the child's due process safeguards: 'guilt is no longer the founding principle ... intervention can be triggered without an 'offence' [actually] being committed, premised instead on a 'condition', a 'character' or a 'mode of life' that is adjudged to be 'failing or posing a 
'risk' (Goldson, 2005a:263). To problematise matters further 'there [is no] substantial evidence [to suggest] that 'risk factor' assessments can predict, with any degree of accuracy, the child offenders of the future' (Goldson, 2005a:263). Nevertheless, this fixation with targeting those thought to be pre-criminal and intervening in their life course to correct their unlawful behaviours, is apparent in the design and delivery of wellestablished YISPs (Goldson, 2005b).

\section{Youth Inclusion and Support Panels}

YISPs target children and young people defined to be 'high risk' of criminal involvement, with a view to counteracting identifiable risk factors that correlate with offending behaviour, via formal statistical identification and the establishment of sophisticated multi-agency partnerships (Smith, 2011). In addition to preventing the young person engaging in criminal activity, YISPs function to help and support young people experiencing difficulties, ensuring that they 'access mainstream services at the earliest possible stage (Case and Haines, 2009:286). In order to determine the level of support required, young people are assessed via the Onset assessment tool - an instrument designed to statistically predict the likelihood in 'at risk' youth engaging in criminal activity.

Essentially embracing a retributive ideology that purports to control the 'dangerous offender', early-preventative YISPs, have been criticised for 'targeting' and 'intervening', unnecessarily, in the life-course of young people thought to be 'pre-criminal' (Sharpe, 2009). YISPs target children and young people on the 'cusp' of entering the Youth Justice System, with a view to preventing the 'onset' of offending. On completion of formal identification, structured packages are provided in 'voluntary' format to counteract identifiable problems. Additionally, positive factors are identified and enhanced through signposting and referral to appropriate services. These programmes, although fixed on correcting young people's deficits, rather than enhancing their positive attributes (Case, 2006) were 
'... apparently designed to 'divert' potential young criminals into 'mainstream' activities and services' (Smith, 2011:133). Perhaps most worryingly, in relation to the establishment of early-preventative measures and most particularly, for the purposes here, the establishment of YISPs, 'young people receiving Onset informed interventions are targeted on the basis of what they are judged (statistically) likely to do, rather than what they have done in respect of actual offending' (Case, 2010:95). This has resulted with the occurrence of ethically immoral judgments portraying young people as 'crime-prone' and 'pre-criminal' (Goldson, 2005a).

Moreover, explicit concern has centred on the lack of general welfare support available for young people prior to referral to the YISP, which means that many of the young people's interrelated and complex educative, family and social difficulties are tackled via resort to the YISP. This 'criminalisation of social policy' (Rodger, 2008) 'has resulted in a blurring of social policy and crime policy in which social problems are reframed as crime problems and crime control strategies are increasingly deployed to manage intractable social ills' (Kemshall, 2007:8). Indeed, the welfare-system has failed to properly support children and young people, in particular girls, with regard to promoting their welfare, and consequently young people experiencing 'welfare' difficulties continue to receive 'much needed' support via crime-prevention early-preventative measures:

... A retrenchment of the welfare state and, in particular, a reduction in services for young people in difficulty, has coincided with the industrial-scale expansion of the youth justice system... offering welfare services to compensate for the state's abrogation of it's responsibilities towards needy and/or vulnerable young people ... drawing [young people] [and] girls [in particular] who are needy or 
'at risk', but who pose no danger to the public, into the criminal justice system.

(Sharpe, 2011:154)

Introducing children and particularly girls', often for committing minor anti-social acts and/or presenting with 'welfare' difficulties, into a punitive system, dominated by risk-led rather than needs-based practice imperatives is certainly concerning, as Sharpe (2011:154) illustrates:

Whilst such an approach may be motivated by benevolent intentions, the penal / punitive framework in which youth justice workers operate, and the risk discourse that dominates contemporary criminal justice practice, ironically serve to render vulnerable children more punishable...

Moreover, when young people are subjected to early-preventative measures, there is minimal emphasis on the deployment of interventions fixed on developing young people's attributes (Goldson and Muncie, 2007). Dominant perceptions of young people as 'problem youth' and 'risky' seem to persist, and influence 'tougher' system responses, further compounding the young people's ability to desist from engaging in criminal activity (Goldson and Muncie, 2007). Furthermore, contemporary responses to 'at risk' youth comprise an emphasis on correcting the young person's identifiable deficits, resulting with, at a practice level, young people stigmatised, labelled, and drawn into the system, unnecessarily (Case, 2006). More than this, the instigation of YISPs and their explicit reference to 'quasi-scientific' risk assessment tools has resulted in young people being scrutinised not only for their present criminal behaviours, but also, for what they are suspected to be capable of doing (Goldson, 2005a). Furthermore, continued use of the Onset assessment tool seems to suggest that the operation of youth justice practice is more-concerned with quantitative statistical outputs rather than qualitative meaningful 
outcomes (Case, 2006; Smith, 2011). Moreover, it is important to note that youth justice professionals tend to statistically 'over predict' the likely occurrence of the offending behaviour of girls, resulting with girls' receiving 'higher levels of youth justice intervention than boys relative to their risk of reoffending' (Nacro, 2008:3). Similarly, the review of provision for girls suggests that girls have higher levels of intervention relative to their risk of reoffending and stipulates that girls respond more negatively to the labelling effect (Bateman, 2008:19).

\section{Youth Justice Responses to Girls}

Early-preventative measures are fixed on demonstrating the young person's potential to be 'risky' and potential to commit crime or anti-social behaviour (Case, 2006). These measures have minimal regard towards enhancing young people's positive attributes, subsequently most clearly hindering the potential for inclusion and integration into mainstream activities (Smith, 2003). These measures appear intent on pre-emptively criminalising young people and most particularly in relation to the YISP evidently drawing young people in for simply 'acting-out' (Walker, et al., 2007).

Importantly, there has been concern regarding the 'appropriateness' of early preventative measures, particularly for girls who have been introduced into the YJS, for apparently experiencing welfare difficulties, either, 'as a result of the criminalisation of domestic disputes or because of concerns about their sexual vulnerability' (Sharpe, 2009:254). Girls have been subjected to forms of intervention, with minimal regard towards their gendered-welfare needs, and continue to feel dissatisfied at the lack of availability in gender specific programmes (Batchelor and Burman, 2004; Bateman, 2008). What's more, this early-preventative method of practice has had a detrimental impact on girls who are 'at risk' of criminal involvement and engaged in the YISP; in particular, most disturbingly resulting with professionals 'confusing "welfare needs" and 
criminogenic risk factors' (Sharpe, 2009:255) and "high need" [girls] becom[ing] "high risk" [girls]' (Worrall, 2001:89). Seemingly, contemporary youth justice policy and professional practice seems to negate the contention that:

When girls raise their sights, broaden their horizons and increase their aspirations and self-esteem, they are less, not more, likely to behave deviantly.

(Worrall, 1999:32)

More disturbingly, the treatment of girls who offend seems to comprise a double penalty: for girls' engaged in criminal activity or thought to be 'at risk' of criminal involvement are not only punished for committing the criminal act, 'they [are also punished] for the 'social' crime of contravening normative expectations of 'appropriate' female conduct ...' (Hudson, 1989:206-207). Indeed girls' have been introduced into the formal youth justice sphere, primarily for concerns regarding behaviour that was deemed to be 'unladylike' (Gelsthorpe and Sharpe, 2006; Sharpe, 2009; Walker, et al., 2007), resulting in the perception of their behaviour as uncontrollable, wayward and unfeminine (Hudson, 1989). Schur (1984:3) captures some of this, and astutely details the implications for girls who are viewed in this negative way:

With great regularity [girls] have been labelled - and they still are being labelled - "aggressive", "bitchy", "hysterical", "fat", "homely", "masculine", and "promiscuous". Judgements such as these, and the social reactions that accompany them, represent a very potent kind of deviance-defining. They may not put the presumed "offender" in jail, but they do typically damage her reputation, induce shame, and lower her "life chances".

Chiefly for concerns regarding their 'sexual vulnerability' and more recently for their perceived 'violent tendencies' (Sharpe, 2009), girls who 
display anti-social or criminal behaviours are continually viewed of as 'uncontrollable' and 'worse than boys' (Gelsthorpe, 2005). What's more, although the number of girls entering the youth justice system for violent offences has significantly increased (Youth Justice Board 2004, 2007, reported a 78 per cent increase in girls' violent offences between 2002/03 and 2005/06 resulting in a substantive disposal), whether the increase is attributed to behaviour changes or an increased punitive, social and/or criminal response is disputed (Steffensmeier, et al., 2005). Interestingly, with reference to the latter, these criminal responses comprise zerotolerance imperatives that draw girls into the remit of youth justice for simply displaying normal childlike behaviours such as 'acting-out' (Chesney-Lind, 2006). Furthermore, Sharpe (2011:153) contends that:

... changes in police and court processing - notably pre-emptive intervention in the name of crime prevention at the 'front end' of the system, and stricter enforcement and less tolerance towards those more deeply entrenched in it - are primarily to blame for the burgeoning population of girls in the youth justice system.

In turn it has been suggested that the dramatic increase in girls entering the YJS (the available data from the Youth Justice Board shows that girls receiving a formal disposal rose by 38 per cent between 2002/03 and 2007/08, (Youth Justice Board, 2004, 2009)), may be partly attributed to the development of more punitive attitudes towards girls' who offend and the instigation of zero-tolerance strategies (Sharpe, 2011). This then, zero-tolerance 'clamp-down' on low-level offending has resulted in an increased resort to forms of corrective-intervention via the formal youth justice apparatus. However, Worrall (1999:41) discerns:

[Although] the criminal justice system is more aware of criminal girls than it was a decade ago ... resulting in some rather strange fluctuations in the sentences they are receiving ... nothing ... 
supports the view that girls are becoming significantly more criminal.

More than this, '... the term 'at risk' is [being] frequently employed to legitimate intervention ...' and in turn, 'girls identified as having the characteristics of becoming a problem [are being] drawn into a net of increasingly intense contact with welfare and justice agencies (Hudson, 1989:202). Moreover, explicit attention has centred upon developing and aspiring towards an 'equitable' youth justice policy and practice agenda, paradoxically resulting, however, in the increased criminalisation of girls' criminal anti-social behaviours (Worrall, 2001). These criminalising practices have resulted with girls' being apprehended for often minor youthful transgressions and exposed to very intrusive, gender-neutral forms of intervention (Batchelor and Burman, 2004; Worrall, 2001). On the other hand - premised upon gender specific ideals - Sharpe (2011) offers alternative perspectives with regard to dominant perceptions portraying girls' as 'problem' 'risky' and 'threatening'. Embracing 'informalist principles' (Cohen, 1985; Goldson, 2005b) this alternative method comprises gender-specific practice imperatives:

... the youth justice system has the potential to normalise offending girls' needs and experiences, rather than single them out as 'bad' girls ... such a normalising strategy may pay dividends by encouraging solidarity and mutual support among girls.

(Sharpe, 2011:152)

Importantly, attention should be redirected towards girls' positive attributes and their gendered-needs rather than their deficits or risky behaviours (Batchelor and Burman, 2004; Bateman, 2008). This fixation with the identification of 'negative behaviours' is likely to be in-effective (Batchelor and Burman, 2004). Rather than focusing on risky-behaviours, aspiring towards an 'equitable' policy and practice agenda requires 
gender-specific practice principles, notably 'harness[ing] the positive aspects of girls' relationships' (Sharpe, 2011:157). Significantly more attention should be given to forming and developing 'effective' and caring relationships with girls' (Worrall, 2001).

The contemporary focus on 'risky youth' has been accompanied by the dominant use of the actuarial paradigm, incorporating the vision of youth as a threat, somewhat harmful for girls, who are significantly vulnerable to lowering self-esteem (Batchelor and Burman, 2004; Bateman, 2008). The construction of girls as troublesome and becoming increasingly violent has hindered the establishment of 'a principled youth justice' (Goldson and Muncie, 2006a) 'with integrity' (Goldson and Muncie, 2007). Risk ideology dominates policy and practice and young people are continually viewed of as threatening as opposed to innocent (Goldson, 2001). This has distracted humanitarian, child and young person centred and gender-specific responses to the offending behaviour of girls (Sharpe, 2011). Importantly, it must be understood that when practitioners are caring and supportive with girls, they speak most positively of the intervention, and report high satisfaction with regard to the outcome (Worrall, 2001).

\section{Concluding Remarks}

... The application of stigmatising labels, followed by negative social reactions, is an inevitable consequence of intervention: the labels produce 'outsiders' and this then necessitates further and more concentrated forms of targeted intervention.

(Goldson, 2000:43)

Early-preventative strategies have been predicated upon seemingly 'commonsensical logic' that intervention is far better than cure (Farrington, 2005) and 'that some groups identified as 'at risk' require and demand disproportionate levels of intervention, and that only an 
individualised or personalised response is likely to be effective (Williamson, 2009:12). Proponents assert that intervening in a young person's life at an early stage can prevent the occurrence of crime and the young person presenting with further difficulties (Sutton, et al., 2004). On the other hand, proponents of the presently unfashionable labelling theory recognise the consequences in being categorised as an 'outsider' (Goldson, 2000) and assert that to define someone in such a way may result in the individual 'eventually believing it themselves, and continuing to behave as a delinquent' (Bell, et al., 1999:92). Indeed, a significant proportion of young people engaged in the YISP developed further problems, and were assessed towards the end of the intervention to present with increased not diminished 'risk-factors' (Walker, et al., 2007), consequently resonating with the observation that:

Premature intervention and formal criminalisation is potentially damaging and counterproductive; it is likely to confirm "delinquent identities" and entrench young people in "criminal pathways"

(Goldson and Yates, 2008:104).

Moreover youth justice professionals provide minimal consideration towards gender-specific matters, and what's more, tend to statistically 'over predict' the offending behaviour of girls, resulting in the deployment of more 'intrusive' measures (Bateman, 2008; Nacro, 2008; Sharpe, 2011). With regard to early-preventative measures, girls have continually been referred to the YISP for expressing welfare difficulties as opposed to displaying crime related problems (Sharpe, 2009). This suggests that girls' should be dealt with via mainstream provision rather than dealt with in the formal youth justice setting. In addition, there have been 'heightened' concerns regarding girls' offending behaviour, as they appear to be 'out-of-control', and drastically committing more criminal offences (and more violent offences in particular), than boys (Sharpe, 2011; Youth Justice Board, 2004, 2009). However, girls' increased levels of offending 
may be a result of 'tougher' criminal responses, and a less tolerant society:

The rise in girls' violence ... is more a social construction than an empirical reality. It is not so much that girls have become any more violent; it is that the avenues to prevent or punish violence have grown so enormously.

(Steffensmeier, et al., 2005:397)

Moreover, it seems that policies need to be re-designed and encapsulate sensitivities towards children and young people, and understand that they are delicate human beings, continually developing and testing boundaries (Case, 2006; Goldson, 2001). Rather than subjecting young people to damaging early-preventative measures and resorting to the formal youth justice process comprising embedded punitive priorities. A principled youth justice system incorporates diversionary principles and informalist strategies premised on a robust evidence-base, 'offer[ing] the prospect of more imaginative, humane, responsive, effective and cost-efficient approaches to troubled and troublesome children and young people' (Goldson, 2005b:236).

\section{Bibliography}

Armstrong, D. (2004) 'A Risky Business? Research, Policy and Governmentality and Youth Offending', Youth Justice 4(2): 100-16.

Armstrong, D. (2006) 'Becoming Criminal: The Cultural Politics of Risk', International Journal of Inclusive Education, 10(2/3): 265-78.

Batchelor, S. and Burman, M. (2004) 'Working with girls and young women' in G. McIvor (ed) Women Who Offend. London: Jessica Kingsley. Pp. 266-287.

Bateman, T. (2008) Review of Provision for Girls in Custody to Reduce Offending, Reading: CfBT Education Trust.

Bell, A., Hodgson, M. and Pragnell, S. (1999) 'Diverting Children and Young People from Crime and the Criminal Justice System', in Goldson, B. 
(ed.) Youth Justice: Contemporary Policy and Practice. Aldershot: Ashgate.

Blackmore, J. (1984) 'Delinquency theory and practice: a link through IT', $^{\prime}$ Youth and Policy, 9.

Burnett, R. (2007) 'Never too early? Reflections on research and interventions for early developmental prevention of serious harm', in Blyth, M., Solomon, E. and Baker, K (eds), Young People and Risk, Bristol: Policy Press.

Case, S. P. (2006) 'Young people "at risk" of what? Challenging riskfocused early intervention as crime prevention', youth justice, 6 (3): 1719.

Case, S. P. (2010) 'Preventing and reducing risk', in Taylor, W. Earl, R. and Hester, R. (eds) Youth Justice Handbook: theory, policy and practice. Cullompton: Willan Publishing.

Case, S. P. and Haines, K.R. (2009) Understanding Youth Offending: Risk Factor Research, Policy and Practice. Cullompton: Willan Publishing.

Chesney-Lind, M. (2006) 'Patriarchy, Crime, and Justice: Feminist Criminology in an Era of Backlash', Feminist Criminology, 1(1): pp.6-26.

Cohen, S. (1985) Visions of Social Control. Cambridge: Polity Press.

Eadie, T. and Canton, R. (2002) 'Practicing in a Context of Ambivalence: The challenge for Youth Justice Workers', youth justice, 2 (14): 14-26. London: The National Association for Youth Justice.

Farrington, D. P. (1997) 'human Development and criminal careers', in M. Maguire, R. Morgan and R. Reiner (eds), The Oxford Handbook of Criminology (2nd edn). Oxford: Oxford University Press.

Farrington, D.P. (2005) 'Early identification and preventative intervention: How effective is this strategy?' Criminology and Public Policy, 4(2): 23748.

Fionda, J. (2005) Devils and Angels: Youth Policy and Crime, Oxford: Hart Publishing.

Garside, R, (2009) Risky people or risky societies? Rethinking interventions for young adults in transition, Transition to Adulthood, London: Centre for Crime and Justice Studies. 
Gelsthorpe, L. (2005) 'Girls in the Youth Justice System', in T. Bateman and J. Pitts (eds) The RHP Companion to Youth Justice. Dorset: Russell House Publishing.

Gelsthorpe, L. and Sharpe, G. (2006) 'Gender, Youth Crime and Justice', in B. Goldson and J. Muncie (eds) Youth Crime and Justice. London: SAGE.

Goldson, B. (2000) 'Wither Diversion? Interventionism and the New Youth Justice', in Goldson, B. (ed.) The New Youth Justice. Lyme Regis: Russell House Publishing.

Goldson, B. (2001) 'The Demonisation of Children: from the symbolic to the institutional', in Foley, P., Roche, J. and Tucker, S. (eds) Children in Society: contemporary theory, policy and practice. Basingstoke: Palgrave.

Goldson, B. (2003) 'Tough on children: tough on justice'. Paper presented at the centre for Studies in Crime and Social Justice (Edge Hill) in collaboration with the European Group for the study of Deviance and Social Control, Chester.

Goldson, B. (2005a) 'Taking liberties: policy and the punitive turn', in Hendrick, H. (ed) Children and social policy: An essential reader, Bristol: The Policy Press.

Goldson, B. (2005b) 'Beyond Formalism: towards 'informal' approaches to Youth Crime and Youth Justice', in Bateman, T. and Pitts, J. (eds.) The Russell House Companion to Youth Justice. Dorset: Russell House.

Goldson, B. and Muncie, J. (2006) 'Critical anatomy: towards a principled youth justice', Goldson, B. and Muncie, J. (eds) Youth Crime and Justice. London: Sage.

Goldson, B. and Muncie, J. (2007) 'Youth Justice with integrity: beyond Allen's "new approach", in Davies, Z and McMahon, W. (eds) Debating Youth Justice: From Punishment to Problem Solving? London: Centre for Crime and Justice Studies.

Goldson, B. and Yates, J. (2008) 'Youth Justice Policy and Practice: Reclaiming applied criminology as critical intervention', in B. Stout and J. Yates (eds) Applied Criminology. London, Sage. 
Hansen, K. and Plewis, I. (2004) Children at Risk: How evidence from British Cohort Data can inform the Debate on Prevention. London: University of London.

Harris, R. and Webb, D. (1987) Welfare, Power and Juvenile Justice. London: Tavistock.

Hudson, A. (1989) 'Troublesome girls': Towards Alternative Definitions and Policies', in M. Cain (ed.), Growing up Good, Policing the Behaviour of Girls in Europe, London: Sage. Pp. 197-219.

Kemshall, H. (2007) Risk assessment and risk management: the rights approach?, in Blyth, M., Solomon, E. and Baker, K (eds), Young People and Risk, Bristol: Policy Press.

Kemshall, H. (2008) 'Risks, rights and justice: understanding and responding to youth risk', youth justice, 8:21-37.

Matza, D. (1969) Becoming deviant, Englewood Cliffs, NJ: Prentice Hall.

Muncie, J. and Hughes, G. (2002) 'Modes of Youth Governance: Political Rationalities, Criminalisation and Resistance', in J. Muncie, G. Hughes and E. McLaughlin (eds) Youth Justice: Critical Readings. London: Sage.

Nacro (2008) Responding to girls in the youth justice system. Youth crime briefing. September 2008. London: Nacro.

Pearson, G. (1983) Hooligan: A History of Respectable Fears. Basingstoke: Macmillan.

Rodger, J. (2008) Criminalising social policy: Anti-social behaviour and welfare in a de-civilised society. Cullompton: Willan Publishing.

Rutherford, A. (1992) Growing out of crime: the new era, London: Waterside Press.

Schur, E. M (1983) Labelling women deviant: Gender, stigma, and social control. Philadelphia: Temple University Press.

Sharpe, G. (2009) 'The Trouble with Girls Today: Professional Perspectives on Young Women's Offending', Youth Justice, 9(3). Pp. 254269.

Sharpe, G. (2011) 'Beyond Youth Justice: Working with Girls and Young Women who Offend', in R. Sheehan, G. McIvor and C. Trotter (eds.) Working with Women Offenders in the Community. Cullompton: Willan. 
Smith, D. and McVie, S. (2003) Theory and method in the Edinburgh of youth transitions and crime. British journal of criminology, 43:169-195.

Smith, R. (2003) Youth Justice: Ideas, Policy and Practice. Cullompton: Willan Publishing.

Smith, R. (2010) 'Children's rights and youth justice: 20 years of no progress', Child Care in Practice, 16: 1, 3- 17.

Smith, R. (2011) Doing Justice To Young People: Youth Crime and Social Justice, Cullompton: Willan Publishing.

Solomon, E. and Blyth, M. (2007) 'Introduction', in Blyth, M., Solomon, E. and Baker, K (eds), Young People and Risk, Bristol: Policy Press.

Squires, P., \& Stephen, A. (2005) Rougher justice. Cullompton: Willan Publishing.

Steffensmeier, D., Schwartz, J., Zhong, H. and Ackerman, J. (2005) 'An assessment of Recent Trends in Girls' Violence Using Diverse Longitudinal Sources: Is the Gender Cap Closing', Criminology 43(2): pp.355-406.

Sutton, C., Utting, D. and Farrington, D.P. (2004) Support from the start: Working with Young Children and their families to Reduce the Risks of Crime and Antisocial Behaviour. London: DfES.

Walker, J., Thompson, C., Laing, K., Raybould, S., Coombes, M., Procter, S. and Wren, C. (2007) Youth Inclusion and Support Panels: Preventing crime and anti-social behaviour?, London: DCSF.

Whyte, B. (2004) 'Effectiveness, Research and Youth Justice', Youth Justice, 1: 3-21.

Williamson, H. (2009), 'Integrated or targeted youth support services: an essay on prevention"', in M Blyth and E Soloman, Prevention and youth crime: Is early intervention working?, Bristol: The Policy Press.

Worrall, A. (1999) 'Troubled or troublesome? Justice for girls and young women' in Goldson, B. (ed.) Youth Justice: contemporary policy and practice, Aldershot: Ashgate.

Worrall, A. (2001) 'Girls at Risk? Reflections on Changing Attitudes to Young Women's Offending', Probation Journal, 48(2): pp.86-92.

Youth Justice Board (2004) Youth Justice Annual Statistics 2002/03. London: Youth Justice Board. 
Youth Justice Board (2007) Youth Justice Annual Statistics 2005/06. London: Youth Justice Board.

Youth Justice Board (2009) Girls and Offending - Patterns, Perceptions and Interventions. London: Youth Justice Board. 